\title{
Review
}

\section{Disciplining the poor: Neoliberal paternalism and the persistent power of race}

\author{
Joe Soss, Richard C. Fording, and Sanford Schram \\ University of Chicago Press, Chicago and London, 2011, ix+368pp., \$25.00, \\ ISBN: 978-0226768779
}

Contemporary Political Theory (2014) 13, e1-e3. doi:10.1057/cpt.2013.4

The law, it seems clear, is powerless alone to destroy racial privilege in the United States. Even after the slave was emancipated, after the law was cleansed of explicit racial bias, and even after laws were passed to explicitly outlaw racial bias and redress racial inequality, Americans still live racially divided and unequal lives. What upholds these racial effects (including racial privilege, racial segregation and racial inequality) even when it is not the law of the land? How can we explain the persistence of racial effects without the evidence of explicit racism?

To solve this puzzle, some social scientists turn to the culture to explain that racial effects are produced by forces raging beyond reach of the law, within a 'culture of dependency' or a 'culture of racism'. Some turn to the psychology of race or racism, to political economy, to the repressive state apparatus or to sexuality among other levels of analysis. The three co-authors of Disciplining the Poor: Neoliberalism and the Persistent Power of Race, Joe Soss, Richard Fording and Sanford Schram, while adopting a 'multi-methods' approach, hone in on poverty governance to explain that racial effects are 'contingent but systematic outcomes depending on the characteristics of decision makers and policy targets, organizational contexts, and political environments' (pp. 14-15). Explicitly bringing political theory to bear on the analysis of public policy, this book argues that federal and state policies are not and need not be racist in order to have racial effects, effects that are prodigiously and persuasively documented in both quantitative and qualitative detail in this book. Therefore, policies and legislation, innocent of overt racism, are not let off the hook but can and should be held accountable for the reproduction of racial inequality and poverty.

Disciplining the Poor demonstrates concretely how the poor are governed, and not merely the recipients of welfare. The authors conceptualize 'poverty governance' as the disciplinary administration of the poor. Poverty governance is undertaken in a dizzying labyrinth of public, private, quasi-public, local, state, federal, non-profit and for-profit, charitable and philanthropic practices. The focus on poverty governance, adapted from Michel Foucault's conception of governmentality, enables the authors to track up, down

(C) 2014 Macmillan Publishers Ltd. 1470-8914 Contemporary Political Theory Vol. 13, 1, e1-e3 
and across that labyrinth to deliver compelling evidence that racial effects are a product of poverty governance rather than the products of welfare policy alone. However, the book combines the ideas that governance is productive (governmentality) and repressive (social control) to tell the story of welfare reform over the last 40 years.

The authors explain (and this is to put a complex, well-told history and a wealth of data provided in the book summarily) that the tremendous growth of the welfare state in the 1960s gave rise to the furious resentment of Whites toward Black women on Aid to Families with Dependent Children (APDC) and their 'dangerous men' in America, a resentment inflamed by the 'southern strategy' of the Republican Party. However, none of that fury produced explicitly racist law or federal legislation. On the contrary, racial effects came to be produced at the administrative levels of state, local, non-profit and for-profit enterprise; that is to say, racial effects are re-produced by poverty governance rather than explicitly directed by the state. The chapter devoted to 'Race and Federalism in Welfare's Disciplinary Turn' began in the 1980s with a welfare state under attack and suffering deep cuts, a decade that saw workfare and other coercive programs, such as Learnfare and Bridefare, tried out at various levels of governance. It ends in the mid-1990s with a fully realized 'devolution revolution' that, we hear so often, lauded as a success because 'the number of AFDC/ TANF recipients in the U.S. declined by 72 percent' (p. 78). Rather than being released to freedom from their 'dependence' upon welfare, however, the poor are 'disciplined': pushed and trained into low-wage and unstable jobs. Thus, the stories of the social control of labor are interwoven in this historical narrative.

Welfare is a close cousin to the prison, and the authors assert, in the 1970s, welfare and penal operations shifted in tandem as two elements of a single apparatus for managing the poor ...'(p. 109). Welfare and the prison underwent similar 'devolutions'. This is one of the many conclusions drawn from an extended quarrel undertaken in the book with Loic Wacquant's Punishing the Poor: The Neoliberal Government of Social Insecurity (2009), which is itself a quarrel with Regulating the Poor: The Public Functions of Welfare (1971), by Frances Fox Piven and Richard A. Cloward. These titles exhibit the duration of a long dispute over the nature of social control in social theory and about the re-production of inequality. As these authors define it in the very first footnote, social control 'refers broadly to the means by which collectives secure adherence to ideational and behavioral norms and curtail disruptive forms of deviance' (p. 309). However, the 'disruption' in question in the 1960s was a powerful welfare rights movement documented by Piven and Cloward, whereas Wacquant and the co-authors are writing about an era when the disruption in question was not a political protest from below, but when crime, drug use, single parent families and moral depravity were targeted from above as disruptive. This raises many questions unanswered in Disciplining the Poor about the targets of social control measures and about the agency of the poor. Nevertheless, in contrast to Wacquant, who argued that the prison displaced welfare as a system of social control, these authors demonstrate that although the welfare rolls are down 72 per cent, poverty governance was 'devolved' rather than simply downsized. 
The 'devolution revolution' that legislators undertook in the 1980s and 1990s to wean individuals off welfare 'dependency' and push them into 'independence' and to take 'personal responsibility' - the adoption of market-based strategies for social change and the weakening of federal entitlements - was combined with the unleashing of new (often federally funded) neoliberal enterprises. Neoliberal reformers 'converged', as the authors put it, with another reform movement waged by neoconservatives, who embraced 'the new paternalism' and who called for authoritarian and federal state-directed strategies for social change. A new governing rationality emerged from the 'convergence of two reform movements' (p. 20), which the authors call 'neoliberal paternalism'. One of the great lessons of this book is that while neoliberal policy promised to set the poor free from the fetters of the federal government, paternalism practiced 'tough love' and governed in the name of 'traditional values' by updating old-fashioned Victorian models of paternalism for governing the poor. The new paternalism is unabashedly authoritarian and aimed to school the poor in the habits and rituals of the market (for example, workfare is the updated workhouse) and to harshly penalize the poor who refused to do as they were told. Yet, neoliberalism (aiming to set us free from governance to take responsibility for ourselves) and paternalism (to unleash state power to impose morality, work and particular sexual behaviors on the poor) are not counter-movements. Disciplinary measures undertaken in name of 'traditional values' guided the same governing institutions that were being devolved to more local levels by neoliberal legislation. Neoliberalism and paternalism were integrated, according to the authors, into 'a shared disciplinary project' (p. 7), pursued by New Democrats and assorted factions of the Republican Party alike.

Although I believe that describing the last 40 years of welfare and penal reform as a 'disciplinary turn' overstates the novelty of those reforms, the authors do point out that neoliberal and paternalist enterprises did not entirely displace the older industrial models of the welfare state and pastoral poverty governance. Instead, neoliberal forces of privatization and market driven rationalities of government joined together - how easily is still an ongoing question - with the forces of state and pastoral paternalism. One of the powerful points made in this book is that 'devolution' is not simply 'privatization', as it is often called by both advocates and critics of neoliberal policy. All the ways in which the poor people are governed have proliferated in assorted public and private relations, blurring, as the authors explain, the boundaries between public and private rather than simply overstepping their bounds.

In sum, Disciplining the Poor makes a welcome contribution to the ongoing project to understand the distinctiveness of the US welfare state. It contributes both to theorizing the relationships between welfare policy, administration and the production of racial effects, and to combatting those effects.

Barbara Cruikshank

University of Massachusetts-Amherst, Amherst, MA 01003, USA 